\title{
Rachel Ashe
}

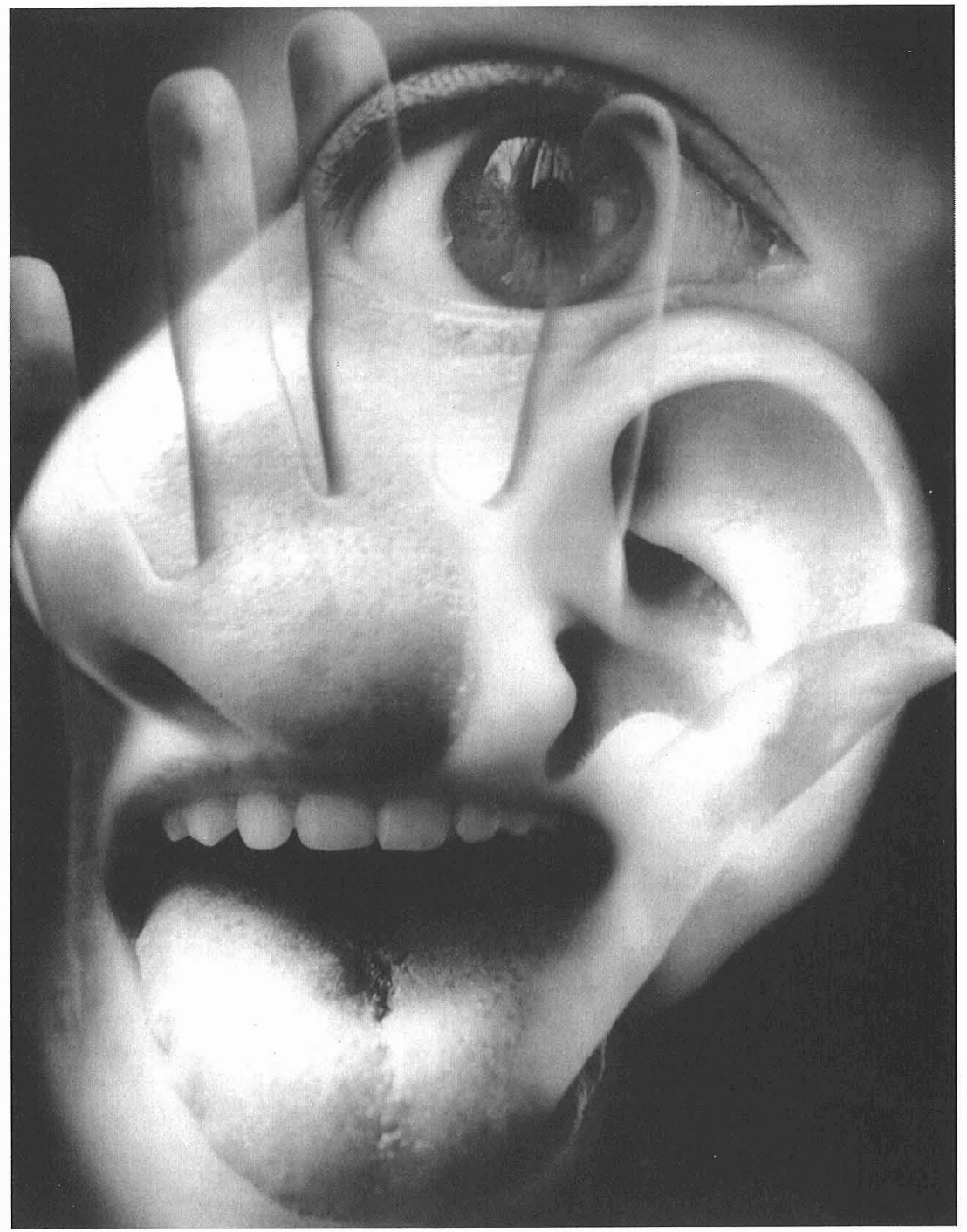

The five senses, 2001, digital image 